\title{
GEOCHEMICAL ASSESSMENT OF THE QUATERNARY SOIL IN SIWA OASIS, WESTERN DESERT, EGYPT
}

El Awady, M. A. M. ${ }^{(1)}$; Abd-Elwahed. A. G. $_{\left({ }^{(2)}\right.}$; Garamoon, H. K. ${ }^{(2)}$ and El Malky, M. G. ${ }^{(3)}$

1) Environmental Monitoring Department, Research and Development Sector, Nuclear Power Plant Authority 2) Geology Department, Faculty of Science, Ain Shams University 3) Basic Environmental Science Department, Institute of Environmental Studies and Research, Ain Shams University

\begin{abstract}
The physicochemical parameters, major ions and heavy metals of the Quaternary cultivated and uncultivated soils in Siwa Oasis were quantitatively determined. Bivariate and multivariate statistical analyses were applied to clarify the relationship between the investigated metals and soil properties and identify the potential sources of these metals in Siwa Oasis soils

The geochemical characteristics of SiwaOasis soils are controlled by several factors,including the nature of parent rocks, geographic location, soil-forming processes, extent of drainage and leaching, effects of saline near-surface groundwater and agriculture practices.
\end{abstract}

Key words: Egypt, Western Desert, Siwa Oasis, Quaternary soils, geochemical assessment.

\section{INTRODUCTION}

Egyptian agricultural lands are increasingly strained due to limited water resources and significant urban encroachment. Nowadays, Egypt is vulnerable to confrontation a serious problem of the shortage in clean and fertile agricultural soil. Recently many efforts were harnessed to increase the agricultural area in Egypt by reclaiming new lands and strict legislation. The Egyptian Ministry of Agriculture announced an effort to reclaim approximately 1.5 million acres $(607,028 \mathrm{ha})$ of marginal or desert lands for agricultural use. 
Siwa Oasis is a promising area for agricultural extension and the associated industrial activities.It comprises a great historic interest due to the presence of Romanic and Pharoanic monuments. Hence, Siwa Oasis is attractive site for tourism. Moreover, the Siwa Oasis is rich in palm and olive trees. Therefore, in recent years, great attention has been directed towards building, agricultural improvement and the construction of agriculturally related industrial projects in this area especially after increasing the population and number of tourists in this area (El-Khoriby and Issa, 1998). Agriculture represents the main activity in Siwa Oasis. Currently, about $88 \mathrm{~km} 2$ (20940 acres) of the oasis are cultivated. This activity depends on theavailability of groundwater from about 1199 wells andsprings, which give a total annual discharge of about255 million m3 (Samy, 2010;Elnaggar et al., 2016; El-Saied, 2017).The cultivated lands in Siwa Oasis suffer from salinization problem. The soil salinization is very high in low lands due tohigh salinity in groundwater, quick capillary rise of water in soilsurface, poor workmanship of pumping water, high evaporation andthe high activity of salt weathering (Abdallah, 2007).

Soil chemical properties can be used as chemical attributes to assess soil quality (Heil and Sposito, 1997). This is important in evaluating the condition and sustainability of soil and to guide soil research, planning and conservation policy (De la Rosa and Sobral, 2008; Masto et al., 2008). Assessing the concentration of potentially harmful heavy metals in the soil is imperative in evaluating its potential risks (Chen et al., 2005). 
The Quaternary soils in Siwa Oasis were subjected to a fewpedogenetic,textural and mineralogical studies by earlier workers (e.g. Saleh, 1970;Harga et al., 1975; Aziz and Fanous, 1979;Abdou et al.,1980 and 1981; ElKhoriby and Issa, 1998; Omran, 2002; Bahanasawy, 2006).The geochemistry of Siwa Oasis soils received attention of recent workers dealing only with soil salinity and degradation (Ismail et al., 2006;Azzam and Salem, 2007;Aly, 2014; Badawy et al., 2015; Elnaggar et al., 2016; Rashed, 2016a and 2016b; Rafie, 2017).

Most of the previous studies on SiwaOasis soils were concerned almost entirely with the soil salinity problemand there is no comprehensive geochemical study. Therefore, the aims of the present work are:(1) to investigate the detailed geochemical characteristics of the varioussoil types in Siwa depressionand assess their possible pollution by toxic metals.

\section{MATERIAL AND METHODS}

1) Study area: Siwa Oasis, almost unique on its own, represents the last virgin oasis in the Western Desert of Egypt. It extends between latitudes $29^{\circ} 05^{\prime}$ and $29^{\circ} 24^{\prime}$ and between longitudes $25^{\circ} 14^{\prime}$ and $26^{\circ} 06^{\prime}$ (Fig. 1).It is located about $560 \mathrm{~km}$ west of Cairo and $300 \mathrm{~km}$ south of the Mediterranean Sea coast. The Siwa depression is about $82 \mathrm{~km}$ long, $21 \mathrm{~km}$ wide with a total area of about $1000 \mathrm{~km} 2$. It lies at about $18 \mathrm{~m}$ below the sea level being completely surrounded by the Sahara Desert (Badawy et al., 2015). The climate of Siwaexhibits extreme aridity from April to November and very lowrainfall from December to March (10 mm/yr on average), andits population increased from about 8,000 residents in 1980 to 28,000 residents in 2016. 
Geomorphologically, the region comprises mainly closed flat depressions bounded from the north by the Marmarica limestone Plateau with a steep escarpment running $\mathrm{E}-\mathrm{W}$ and from the south by areas of mobile sand dunes. Playas, saline lakes, and cultivated land are the main habitats of the closed flat depressions (Abdel-Motelib et al., 2015).

From a geological point of view, three main lithologic units of the Middle Miocene age are extensively exposed in Siwa: a lower older Siwa Oasis Member, forming the floor of the depression and consisting mainly of shale and marl; a middle Siwa Escarpment Member, forming the escarpment and the slope of the detached hills; and an upper El-Diffa Plateau Member, occupying the upper surface of the plateau. The escarpment and the plateau consist principally of chalky limestone, limestone, and dolomitic limestone (Gindy and El-Askary, 1969).Structurally, Siwa Oasis occupiesa regional NNW-SSE synclinal fold and is characterized by well-developed NW-SE and ENE-WSW 


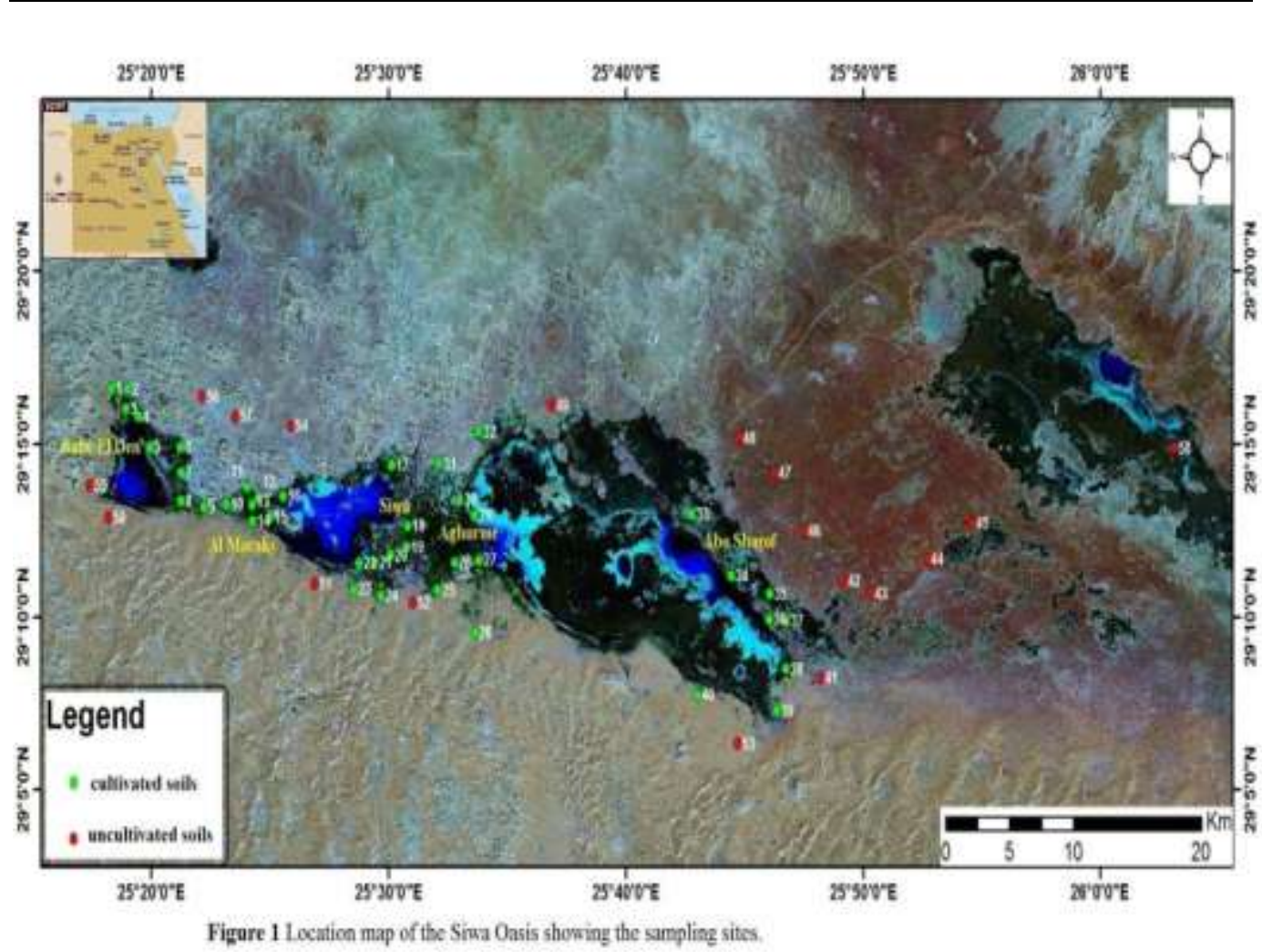

Structural lineaments (El Shazly et al., 1978). The tectonicevolution in the Siwa area indicates a complicated geologic historyof uplift and subsidence with developed folds, horsts, and grabens (RizkallaandAwad, 1990).

2) Sampling: A total of fifty-eighttop soil samples $(0-20 \mathrm{~cm}$ depth) were collected fromthestudy area. Forty samples were collected from the cultivated landrepresenting the main suburbs in the Siwa Oasis; eighteen samples were collected from the barren areas representing the uncultivated soils with special attention to the north-eastern part (Fig. 1). From every sampling point, up to 5 subsamples $(50 \times 50 \mathrm{~m} 2)$ were collected and aggregated to obtain a bulk sample; weighting up to $500 \mathrm{~g}$. Soil sample was collected in sealed 
polyethylene bags using a clean stainless steel shovel to avoid any contamination.

3) Samples treatment and chemical analysis: After removal of recognizable plant debris and stones, the air-dried soil sample was sieved through $2 \mathrm{~mm}$ sieve before analysis. Soil organic matter content (OM) was measured by loss in ignition followed the procedure adopted by Van Reeuwijk (2002). Clay content was measured using pipetting analysis followed the procedure adopted by Lewis andMcConchie(1994).pH and EC were determined in aqueous soil suspensions ( 1 soil:2.5 water) followed the procedure adopted by Pansu and Gautheyrou (2006).

These samples were subjected to chemical analysis. The concentrations of the major cationswere determined in the soil extract (1:2.5) using Inductively Coupled Plasma-Optical Emission Spectroscopy(ICP-OES) with ultrasonic Nebulizer (USN)(Perkin Elmer Optima 3000, USA). Major anions were determined using Ion Chromatography (IC) applying model DX-500 chromatography system.Total metals content were extracted using microwave digestion techniques as reported by Littlejohn et al. (1991).

4) Statistical treatment: Descriptive statistics and multivariate statistical analysis were determined for the studied soils by using SPSS (version 21). Sampling sites locations in the study area were presented by using Arc GIS (version 9.3). Pearson correlation coefficient matrix was calculated to define the correlations between the different heavy metal pairs and interrelationship between heavy metal levels and OM \% and clay content in soil samples. Also, 
Cluster analysis (CA) was used to identify the sources contributing to the soil heavy metal contamination and their controlling factors.

\section{RESULTS AND DISCUSSION}

1) Physicochemical parameters: Organic matter $(\mathrm{OM})$ could play a significant role in the retention of heavy metals in soils due to its strong adsorption (Guo et al., 2006; Micó et al., 2006). Among the various grain size classes' clay size plays a significant role in distribution of heavy metal in soi samples.Table (1) and Figure (2) show that Soil organic matter (OM\%) and clay\% 
J. Environ. Sci.

Institute of Environmental Studies and Research - Ain Shams University

Table (1): The descriptive statistical parameters of the investigated physicochemical properties, major ions and heavy metals.

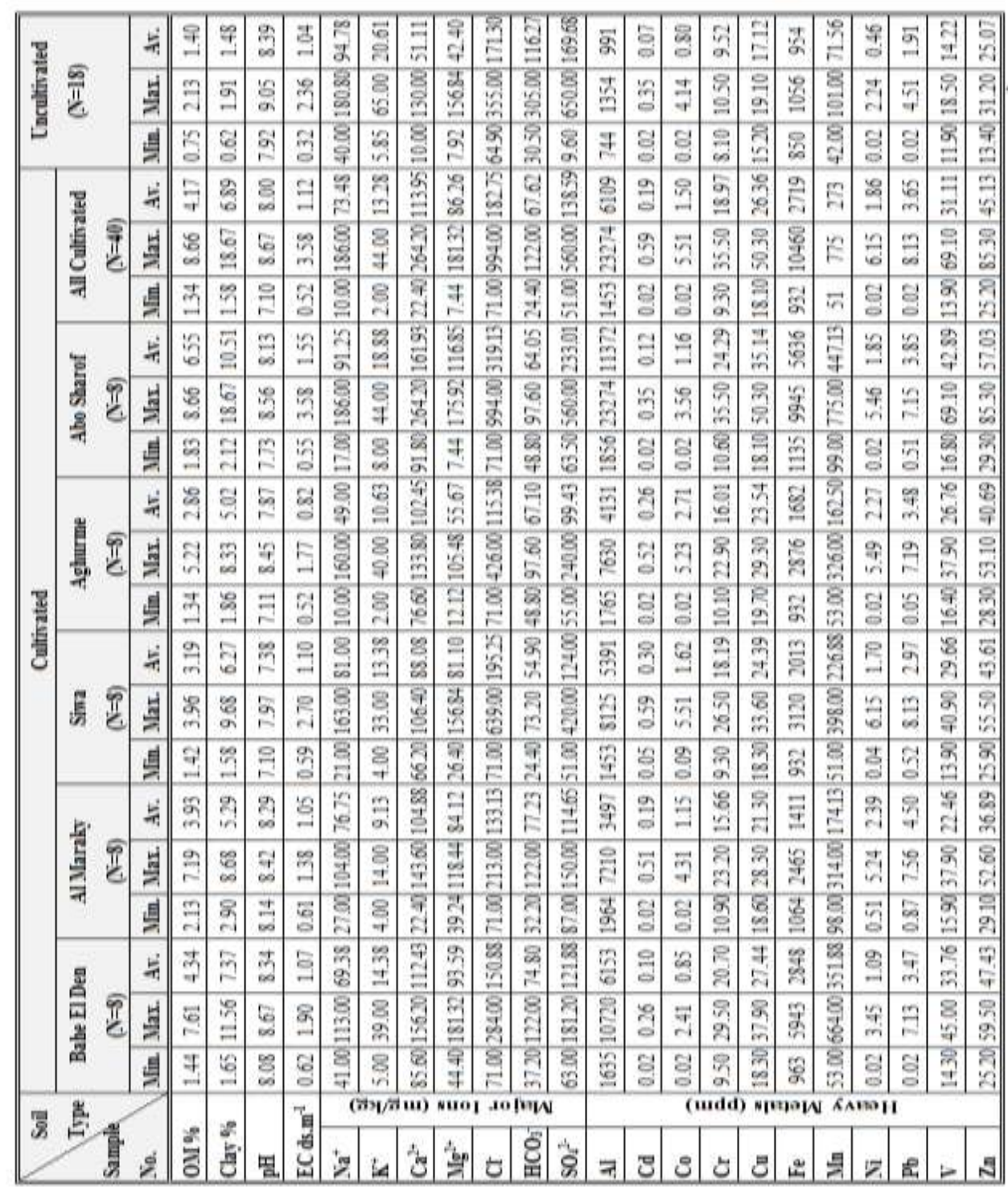




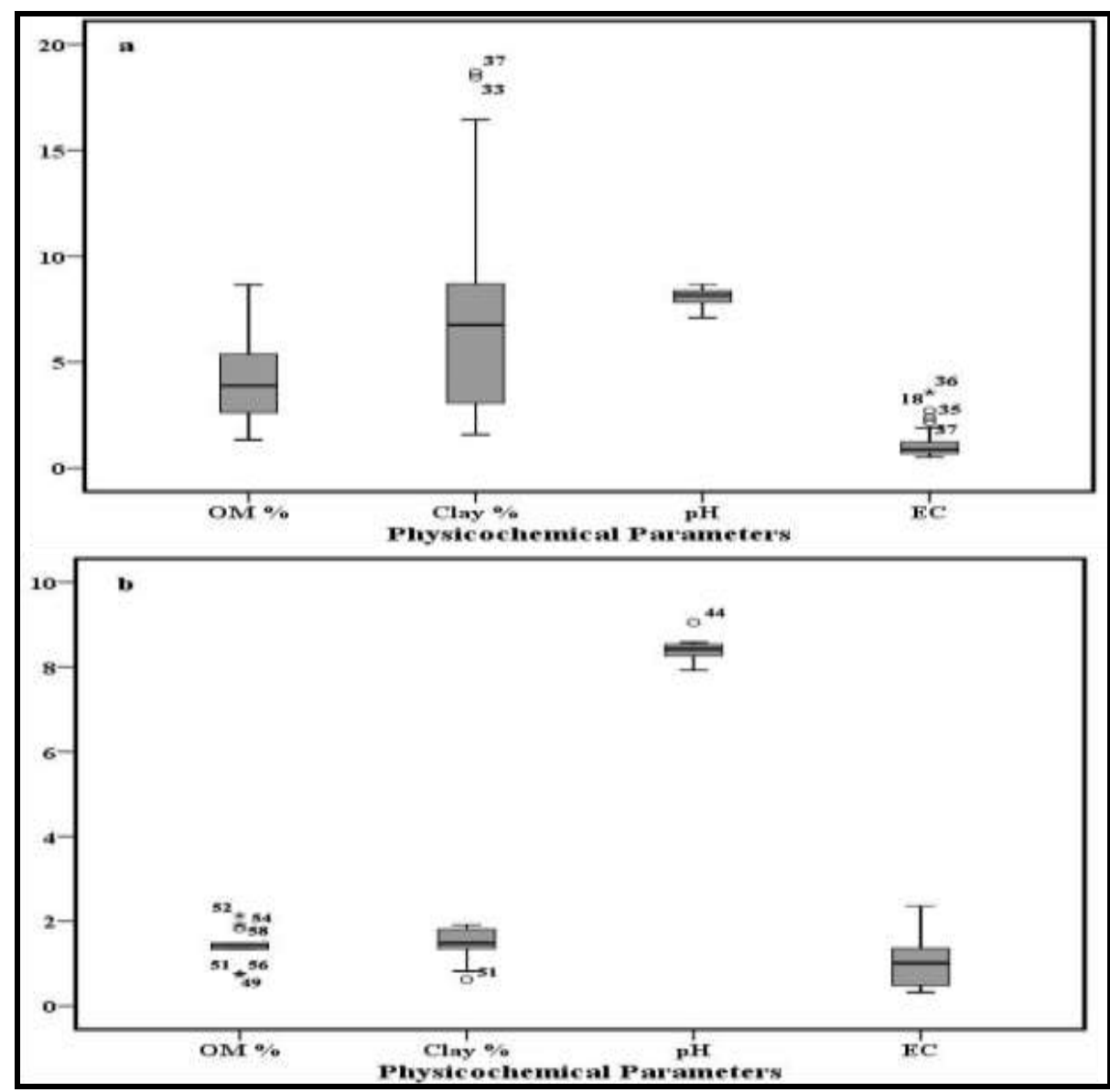

Figure (2): Boxplots of the physicochemical parameters in the studied cultivated (a) and uncultivated (b) soils of Siwa Oasis.

ofthe cultivated soil samples range from 1.34 to $8.66 \%$, with an average value of $4.17 \%$ and from 1.58 to $18.67 \%$, with an average value of $6.89 \%$, respectively. On the other hand, the uncultivated soil samples show low content of $\mathrm{OM}$ and clay ranging from 0.75 to $2.13 \%$, with an average value of $1.40 \%$, and from 0.62 to $1.91 \%$, with an average $1.48 \%$, respectively.

$\mathrm{pH}$ is one of the most important soil properties that affect the availability ofelements.The cultivated and uncultivated soils in Siwaoasisare slightly 
alkaline having $\mathrm{pH}$ values ranging from7.10 to 8.67 and 7.29 to 9.02; respectively. The alkalinity of these soils is related to the composition of the soil parent rocks which mainly composed of limestone and shale. On the other hand, these soils exhibit a wide range of EC values of the cultivated soils (0.52-3.58, average $1.12 \mathrm{dsm}^{-1}$ )are slightly higher than those of the uncultivated soils (0.322.3 , average $1.04 \mathrm{dsm}^{-1}$ ).

Based on their slight alkalinity, significant varying salinity and development under hyper-arid conditions, the Siwa soils belong to the saline desertic subgroup of the intrazonal group in the world pattern of soils (Ollier, 1979).

2) Major ions: Differences in chemistry of Siwa soils are expressed by differences in the relative abundances of the major cations $\left(\mathrm{Ca}^{++}, \mathrm{Mg}^{++}, \mathrm{Na}^{+}\right.$ and $\left.\mathrm{K}^{+}\right)$and anions $\left(\mathrm{Cl}^{-}, \mathrm{HCO}_{3}{ }^{--}\right.$and $\left.\mathrm{SO}_{4}^{--}\right)$. These differences are attributed primarily to differences in mineral composition. The recorded cations and anions constitute the major parts of clay minerals, calcite, dolomite, halite and gypsum which exist in different proportions in the different soil types as reported by Bahanasawy(2006).

$\mathrm{Ca}^{++}$and $\mathrm{Mg}^{++}$are the most dominant major cations in the cultivated soils of Siwa Oasis (Table 1 and Fig. 3). They are followed by $\mathrm{Na}^{+}$and $\mathrm{K}^{+}$. On the other hand, theuncultivated soils are characterized by the marked dominance of $\mathrm{Na}$ followed by $\mathrm{Ca}^{++}, \mathrm{Mg}^{++}$and $\mathrm{K}^{+}$. The depletion of the cultivated soils in Na may be due to the dissolution of halite by irrigation water and/or cation exchange with $\mathrm{Ca}^{++}$and $\mathrm{Mg}^{++}$. The major anions in the cultivated and uncultivated Siwa soils areArranged in the order of decreasing abundanceCl-, $\mathrm{SO}_{4}^{--}$, and $\mathrm{HCO}_{3}^{--}$ (Fig. 4). 
The recorded high concentrations of $\mathrm{Ca}$ and $\mathrm{Mg}$ may be inherited from the exposed rocks which mainly composed of limestone and shale. The relatively high salinity expressed by high concentrations of $\mathrm{Na}^{+}, \mathrm{Cl}^{-}$and $\mathrm{SO}_{4}^{--}$recorded in these soils is related to the saline near-surface underground waters and/or inadequate drainage rather than their proximity to playa lakes.

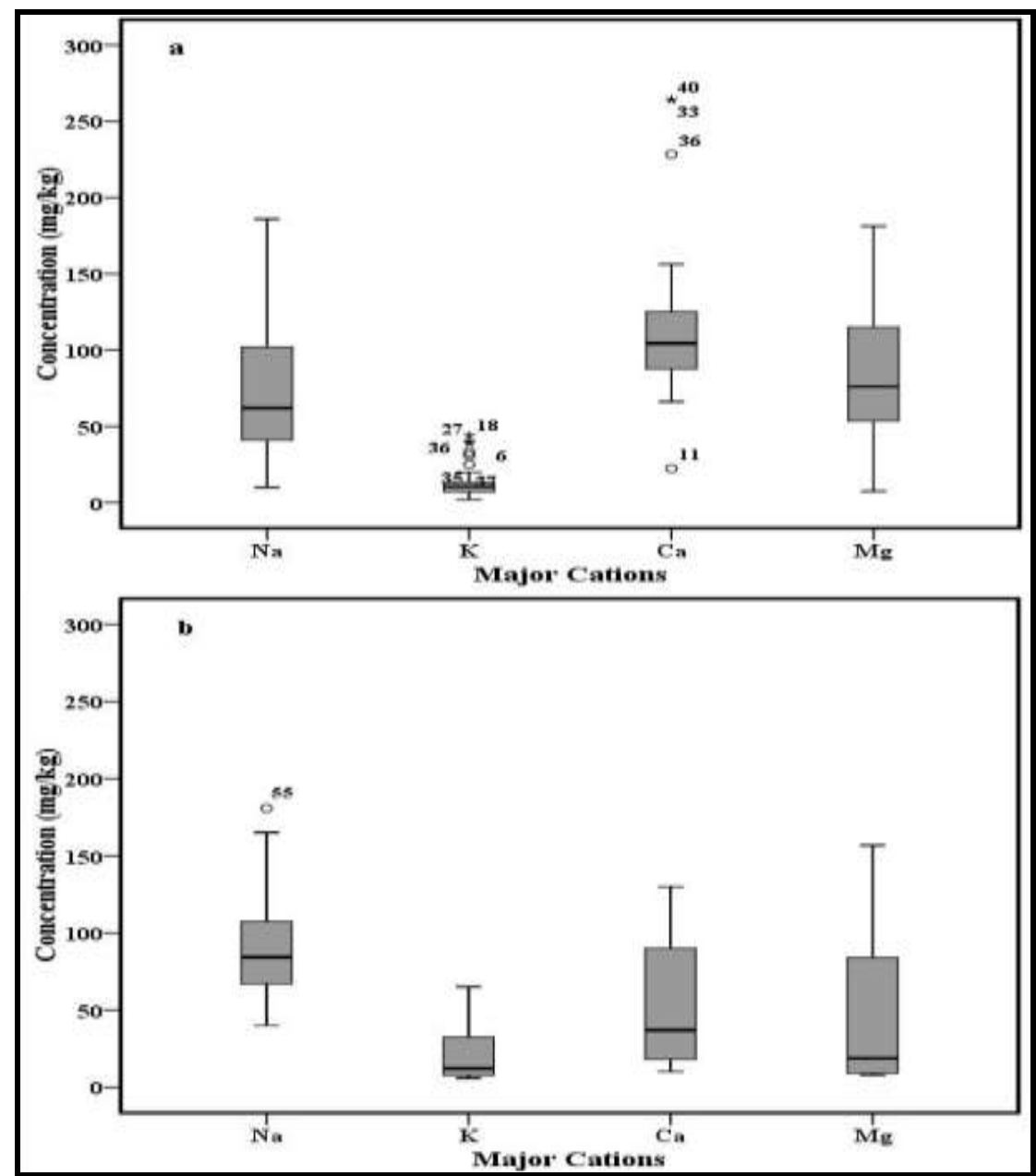

Figure (3): Boxplots of the major cations in the studied cultivated (a) and uncultivated (b) soils of Siwa Oasis. 
J. Environ. Sci.

Institute of Environmental Studies and Research - Ain Shams University

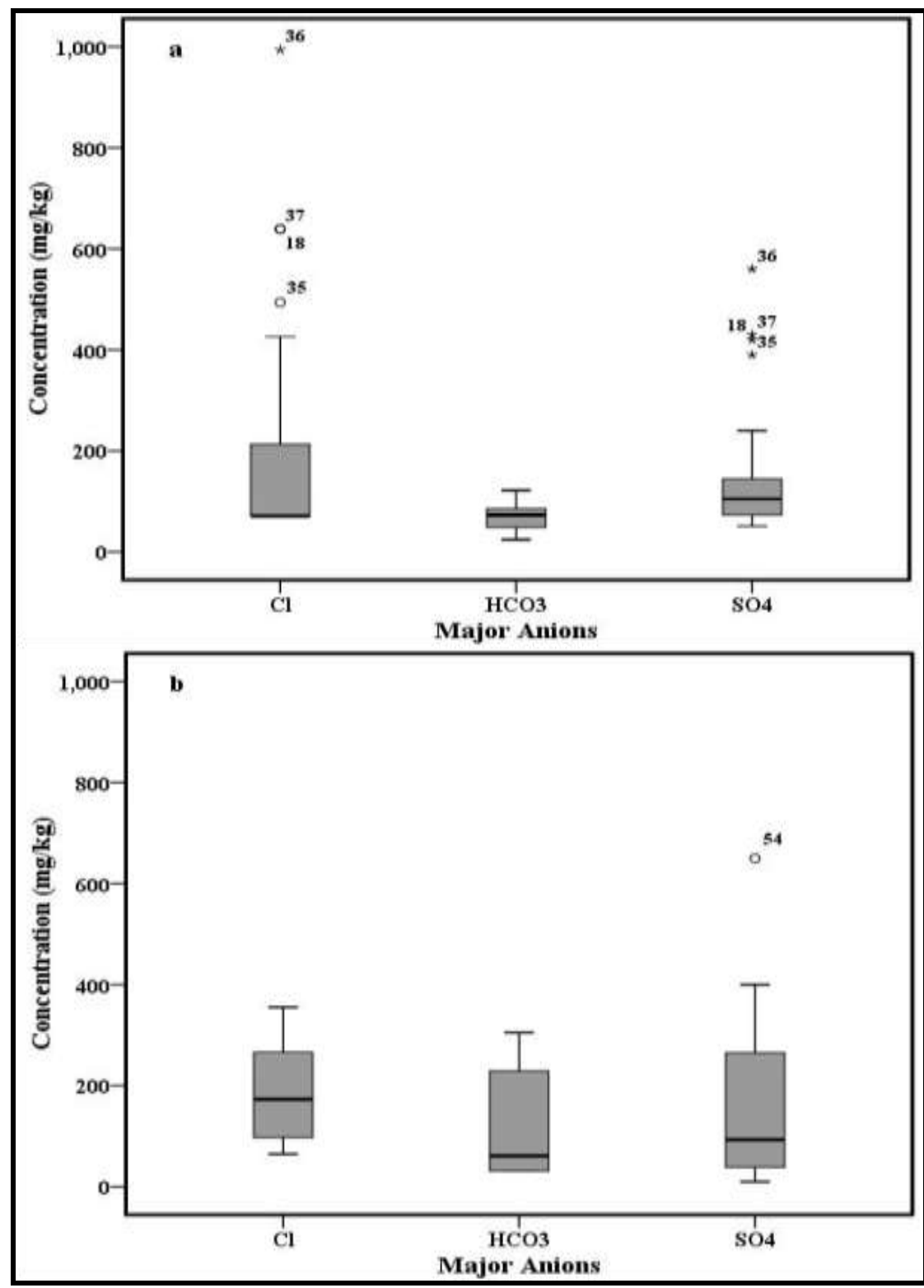

Figure (4): Boxplots of the major anions in the studied cultivated (a) and uncultivated (b) soils of Siwa Oasis. 
3) Metal Distribution: Table (1) shows that $\mathrm{Al}, \mathrm{Fe}$ and, to a much lesser extent, Mn are the most abundant metals in the Siwa cultivated and uncultivated soils. $\mathrm{Zn}, \mathrm{V}, \mathrm{Cu}$ and $\mathrm{Cr}$ exist in minor concentrations. Generally, the concentrations of the investigated metals (fig 5) $\mathrm{Al}, \mathrm{Cd}, \mathrm{Co}, \mathrm{Cr}, \mathrm{Cu}, \mathrm{Fe}, \mathrm{Mn}$, $\mathrm{Ni}, \mathrm{Pb}, \mathrm{V}$ and $\mathrm{Zn}$ in the cultivated soils range from 1453 to $23274,0.02-0.59$, $0.02-5.51,9.30-35.50,18.10-50.30,932-10460,51-775,0.02-6.15,0.02-$ $8.13,13.90-69.10$, and $25.20-85.30 \mathrm{ppm}$, respectively. On the other hand, they range from 744 to $1354,0.02-0.35,0.02-4.14,8.10-10.50,15.20-19.10$, 850-1056, 42-101, 0.02-2.24, 0.02-4.51, 11.90-18.50, and 13.40-31.20 ppm in the uncultivated soils, respectively.

The mean concentrations of these metals in the cultivated soils followed the order $\mathrm{Al}>\mathrm{Fe}>\mathrm{Mn}>\mathrm{Zn}>\mathrm{V}>\mathrm{Cu}>\mathrm{Cr}>\mathrm{Pb}>\mathrm{Ni}>\mathrm{Co}>\mathrm{Cd}$; while those of the uncultivated soils followed the order $\mathrm{Al}>\mathrm{Fe}>\mathrm{Mn}>\mathrm{Zn}>\mathrm{Cu}>\mathrm{V}>\mathrm{Cr}>\mathrm{Pb}>\mathrm{Ni}$ $>\mathrm{Co}>\mathrm{Cd}$ (Fig.4).Interestingly, the concentrations of all investigated metals are higher in the cultivated soils than the uncultivated soils. Also, their concentrations don't exceed the maximum allowable limits for metal in agricultural soil (Table 2). 
J. Environ. Sci.

Institute of Environmental Studies and Research - Ain Shams University

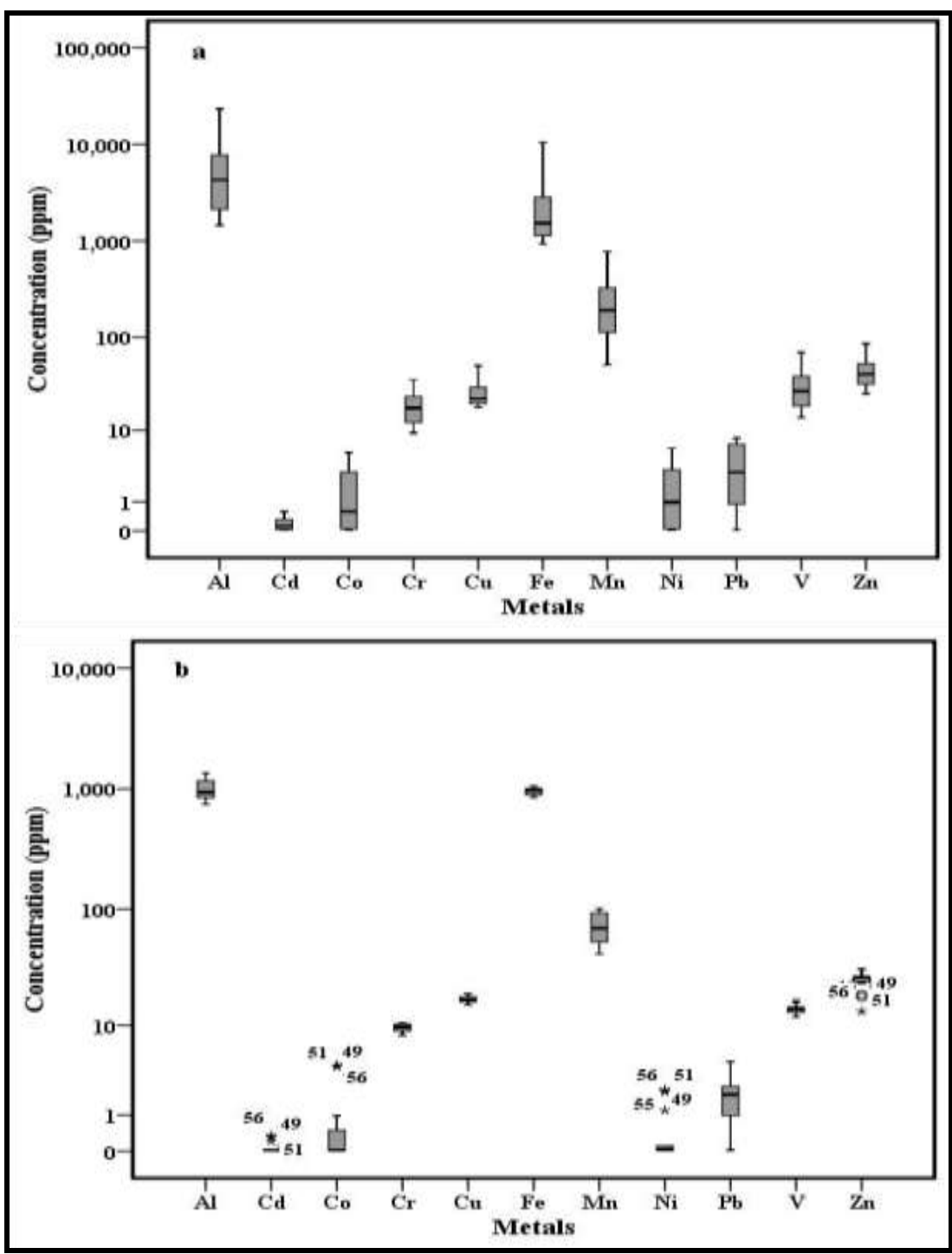

Figure (5): Boxplots of the metals in the studied cultivated (a) and uncultivated (b) soils of Siwa Oasis. 
Table (2): Values of maximum allowable limits (M.A.L.) for heavy metals in soil (ppm) used in different countries (in Kabata-Pendias, 1995)

\begin{tabular}{|c|c|c|c|c|c|c||}
\hline Metal & Austria & Canada & Poland & Japan & UK & Germany \\
\hline $\mathrm{Cd}$ & 5 & 8 & 3 & - & 3 & 2 \\
$\mathrm{Co}$ & 50 & 25 & 50 & 50 & - & - \\
$\mathrm{Cr}$ & 100 & 75 & 100 & - & 50 & 200 \\
$\mathrm{Cu}$ & 100 & 100 & 100 & 125 & 100 & 50 \\
$\mathrm{Ni}$ & 100 & 100 & 100 & 100 & 50 & 100 \\
$\mathrm{~Pb}$ & 100 & 200 & 100 & 400 & 100 & 500 \\
$\mathrm{~V}$ & 100 & 130 & 100 & 150 & 100 & 200 \\
$\mathrm{Zn}$ & 300 & 400 & 300 & 250 & 300 & 300 \\
\hline \hline
\end{tabular}

4) Metal Sources and Interaction: Bivariate and multivariate statistical analyses are used to clarifythe relationship between the recorded metals and soil properties in addition to metal sources in the studied soils, these analyses are Pearson's correlation coefficient (PCC), and hierarchical cluster (HCA).Themost of the recorded metals (Table 3) had a significant positive correlation $(>0.5)$ with $\mathrm{OM} \%$, clay $\%$ and with each other.On the other hand $\mathrm{Cd}, \mathrm{Co}, \mathrm{Ni}$ and $\mathrm{Pb}$ had a significant positive correlation $(>0.5)$ with each other and negative correlation with OM \%, clay $\%$ and the rest of metals. This conclusion indicates that these metals possibly originated from different sources. 
J. Environ. Sci.

Institute of Environmental Studies and Research - Ain Shams University

Table (3): Pearson's correlation coefficient for the studied variables $(\mathrm{n}=58)$

\begin{tabular}{|c|c|c|c|c|c|c|c|c|c|c|c|c||}
\hline & Clay \% & Al & Cd & Co & $\mathbf{C r}$ & $\mathbf{C u}$ & $\mathbf{F e}$ & $\mathbf{M n}$ & $\mathbf{N i}$ & $\mathbf{P b}$ & $\mathbf{V}$ & $\mathbf{Z n}$ \\
\hline \hline $\mathbf{O M} \%$ & .68 & .65 & -.58 & -.53 & .67 & .67 & .65 & .69 & -.45 & -.46 & .67 & .66 \\
\hline $\begin{array}{c}\text { Clay } \\
\text { \% }\end{array}$ & & .97 & -.70 & -.67 & .98 & .96 & .92 & .95 & -.71 & -.66 & .98 & .98 \\
\hline $\mathbf{A l}$ & & & -.60 & -.56 & .92 & .96 & .95 & .91 & -.59 & -.54 & .96 & .96 \\
\hline $\mathbf{C d}$ & & & & .86 & -.73 & -.60 & -.52 & -.64 & .82 & .74 & -.68 & -.69 \\
\hline $\mathbf{C o}$ & & & & & -.70 & -.55 & -.46 & -.61 & .82 & .74 & -.62 & -.64 \\
\hline $\mathbf{C r}$ & & & & & & .96 & .86 & .96 & -.75 & -.73 & .96 & .96 \\
\hline $\mathbf{C u}$ & & & & & & & .93 & .97 & -.58 & -.56 & .96 & .95 \\
\hline $\mathbf{F e}$ & & & & & & & & .88 & -.48 & -.39 & .92 & .91 \\
\hline $\mathbf{M n}$ & & & & & & & & & -.62 & -.59 & .94 & .93 \\
\hline $\mathbf{N i}$ & & & & & & & & & & .92 & -.71 & -.73 \\
\hline $\mathbf{P b}$ & & & & & & & & & & & -.67 & -.68 \\
\hline $\mathbf{V}$ & & & & & & & & & & & & .99 \\
\hline
\end{tabular}

(HCA) (Fig. 6) generated similar results with those of PCC. HCA can be divided into two major clusters (A and $\mathrm{B}$ ): Cluster $(\mathrm{A})$ : can besplatted into $\mathrm{A}^{-1}$ subcluster $(\mathrm{Cu}, \mathrm{Zn}, \mathrm{Cr}, \mathrm{V}$, and $\mathrm{OM} \%)$ and $\mathrm{A}^{-2}$ subcluster (Al, Fe, clay \% and $\mathrm{Mn}) . \mathrm{A}^{-1}$ subclusterindicates that the $\mathrm{Cu}, \mathrm{Zn}, \mathrm{Cr}$ and $\mathrm{V}$ associated with soil $\mathrm{OM}$ and possibly originated from natural source. The heavy metals of $\mathrm{A}^{-1}$ subcluster have the affinity for allumino-sillicate phase and soil's Fe-Mn oxides which are important products of parent rock weathering. $\mathrm{Cr}^{+3}$ may exist as a substituent of $\mathrm{Fe}^{+3}$ and/or $\mathrm{Al}^{+3}$ in their compounds. Also, $\mathrm{V}$ may be admitted in the crystal structures of ferric compounds. Cluster (B)includes $\mathrm{Cd}, \mathrm{Co}, \mathrm{Ni}$ and $\mathrm{Pb}$ which indicated that these heavy metals were possibly originated anthropogenically from the agricultural practices and newly constructed industrial activities. This conclusion is confirmed by the significant negative correlation between heavy metals of cluster (B) and OM, clay, Al, Fe and Mn of cluster (A). 


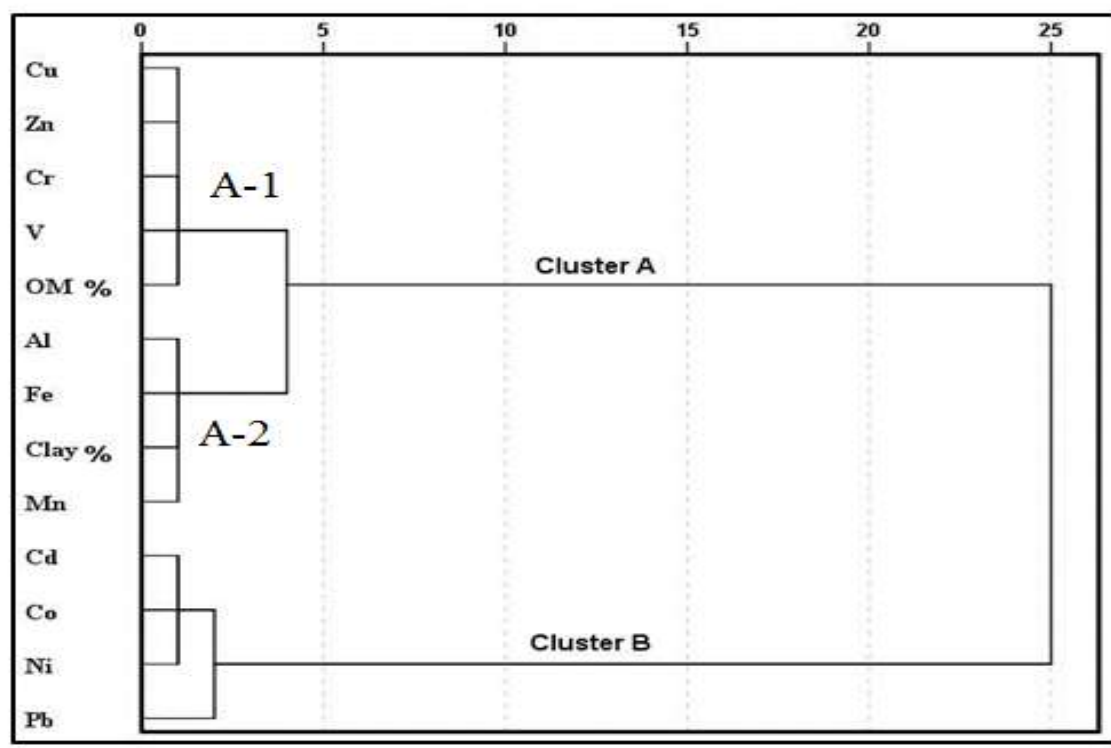

Figure 6 Dendrograms of the investigated metals using Ward's method

\section{CONCLUSIONS}

The development of Siwa Oasis Quaternary soils under hot dry climatic conditions resulted in their slight alkalinity and considerable salinity. Differences in their chemical constituents are attributed to the differences in parent rocks as well as local conditions such as location, extent of drainage and leaching, effects of near-surface saline groundwater and agriculture practices.

The cultivated Siwa soils are invariably more enriched with heavy metals than the uncultivated soils. The associations that exist between the soil components in Siwa Oasis indicate their inheritance from geogenic and anthropogenic sources by the effects of weathering processes and agricultural and industrial activities which enhance the accumulation of heavy metals. 
J. Environ. Sci.

Institute of Environmental Studies and Research - Ain Shams University

\section{REFERENCES}

Abdallah, A. (2007): Assessment of salt weathering in Siwa Oasis(The Western Desert of Egypt).Bull. De la Soc. De Geog. De Egypt, 80:66-83.

Abdel-Motelib, A., Taher, A. and El Manawi, A. (2015): Composition and diagenesis of ancient Shali city buildings of evaporate stones (kerchief), Siwa Oasis, Egypt. Quat.Int., 369:78-85.

Abdou, F.M., Aziz, M.A. andFanous, N.E. (1980): Mineralogy of the sand fraction of some soils and sediments of Siwa Depression, Western Desert, Egypt. Res. Bull., Fac. Agri., Ain Shams Univ.,2(1):19-35.

Abdou, F.M., Aziz, M.A., Fanous, N.E. (1981): Mineralogical composition of the clay fraction of the soils of Siwa Oasis Western Desert of Egypt. Egypt J. Soil Sci., 21(1):61-78.

Aly, A.A. (2014): .Impact of irrigation management on shallow groundwater fluctuation and soil salinity: the saltmed model.Egypt J. Soil Sci., 54(4):355-371.

Aziz, M.A and Fanous, N.E. (1979): .Mechanical composition and mechanism of transportation of some soils of Siwa oasis [sand, sandy loam, loamy sand, loamy and sandy clay loam; Egypt].Res. Bull., Fac. Agri., Ain Shams Univ., 1(1):48-63.

Azzam, M.A. and Salem, M.Z. (2007).Studies on some soils of Siwa oasis: 2soil classification and land suitability, evaluation of Siwa and Aghormi regions. Egypt J. Agric. Res., 85(6):1955-1978.

Badawy, W.M., Ali, K., El_Samman, H.M., Frontasyeva, M.V., Gundorina, S.F. and Duliu, O.G. (2015): Instrumental Neutron Activation Analysis of Soil and Sediment Samples from Siwa Oasis, Egypt.Phys. Part.Nucl.Lett., 12 (4):637-644.

Bahanasawy, N.M. (2006): Mineralogical study of some soil units in Siwa Oasis, Egypt.Ph.D. Thesis, Fac. Agric., Benha, Univ., Egypt.180 p.

Chen, T.B., Zheng, Y.M., Lei, M., Huang, Z.C., Wu, H.T., Chen, H., Fan, K.K., Yu, K., Wu, X. and Tian, Q.Z. (2005): Assessment of heavy metal pollution in surface soils of urban parks in Beijing, China.Chemosphere, 60: 542-551. 
De la Rosa, D. and Sobral, R. (2008): Soil quality and methods for its assessment. In: Braimoh, A.K. and Vlek P.L.G. (Eds.), Land use and soil resources. Springer.

El Shazly, E.M., AbdelHady, M.A. and ElShazly, M.M. (1978): Application of Landsat imagery in thegeological and soil investigations in the central Western Desert, Egypt.Int. Symp. RemoteSens. Environ. Proc., 12(2):857-66.

El-Khoriby, E.M. and Issa, Gh.I.(1998): Sedimentology and mineralogy of recent continental sabkhas, siwa depression, WesternDesert, Egypt.Egyptian J. Geol., 42(2):621-640.

Elnaggar, A.A., Mosa, A., El-Seedy, M.E. and Biki, F.G. (2016): Evaluation of soil agricultural productive capability by using remote sensing and GIS techniques in Siwa Oasis, Egypt.J. SoilSci. Agric. Eng. Mansoura Univ., 7(8):547-555.

El-Saied, A. (2017): Monitoring and assessment of environmental changes in Siwa Oasis, Egypt.J. Agri. Eco. Res. Int., 13(1): 1-14.

Gindy, A.R. and El Askary, M.A. (1969): Stratigraphy, structure and origin of the Siwadepression, Western Desert of Egypt.AAPG Bull., 9:603662 .

Guo, X., Zhang, S., Shan, X.Q., Luo, L., Pei, Z., Zhu, Y.G., Liu, T., Xie, Y.N. and Gault, A. (2006): Characterization of $\mathrm{Pb}, \mathrm{Cu}$, and $\mathrm{Cd}$ adsorption on particulate organic matter in soil.Environ.Toxicol.Chem., 25:2366-2373.

Harga, A.A., Hammad, M.M. and Abd El-Salam, M.A. (1975): The soils of Siwa Oasis.DesertInst. Bull. ARE, 25(1):173-186.

Heil, D. and Sposito, G. (1997): Chemical attributes and processes affecting soil quality. Developments in Soil Sci., 25:59-79.

Ismail, H.A., Morsy, I.M., Abd El-Kawy, O.R. and Soliman, W.A. (2006): Integrating GIS and RS for land reclamation at Siwa Oasis.Egypt. J. Soil Sci., 46(4):377-389. 
Kabata-Pendias, A. (1995): Agricultural Problems Related to Excessive Trace Metal Contents of Soil, in "Heavy Metals (Problems and Solutions)", (Ed. W. Salomons, U. Förstner and P. Mader), Springer Verlag, Berlin, Heidelberg, New York, London, Tokyo, 3-18.

Lewis, D.W. and McConchie, D. (1994): Analytical Sedimentology.Springer, Netherlands.

Littlejohn, D., Egila, J.N., Gosland, R.M., Kunwar, U.K. and Smith, C. (1991): Graphite furnace analysis.Anal.Chim.Acta., 250:71-84.

Masto, R.E., Chhonkar, P.K., Singh, D. and Patra, A.K. (2008): Alternative soil quality indices for evaluating the effect of intensive cropping, fertilisation and manuring for 31 years in the semi-arid soils of India.Environ.Monit.Assess., 136:419-435.

Micó, C., Recatalá, L., Peris, A. and Sánchez, J. (2006): Assessing heavy metal sources in agricultural soils of an European Mediterranean area by multivariate analysis. Chemosphere, 65:863-872.

Ollier, C.D. (1979):.Weathering, Geomorpology.Text 2, Longman, London, New York.

Omran, A.M. (2002): Pedogenesis and mineralogy of soils in Siwa Oasis, Egypt.M.Sc. Thesis, Fac. Agric.Minufia Univ., Egypt. 120p.

Pansu, M. and Gautheyrou, J. (2006): Handbook of soil analysis: mineralogical, organic and inorganic methods.Springer, Netherlands.

Rafie, R.M. (2017): Effect of water table level on soil and wheat productivity inSiwaOasis.Egypt. J. Soil Sci., 57(1):89-100.

Rashed, H.S. (2016a): Change detection in land degradation and environmental hazards sensitivity in some soilsof Siwa Oasis. Egypt. J. Soil Sci., 56(3):433-451.

Rashed, H.S. (2016b): Evaluation of Sustainable Land Management onSome Selected Soils of Siwa Oasis.Egypt. J. Soil Sci., 56(3):453-470.

Rizkalla, I.R. and Awad, B.M. (1990): Modelling of the basement surface of Siwa Qattara depressionarea, northern Western Desert of Egypt.QatarUniv.Sci. Bull.,10:339-62. 
Saleh, H.H. (1970): Pedological study on Siwa Oasis soils. M.Sc. Thesis, Fac. Agric. Cairo Univ. Egypt.

Samy, A.R. (2010): A Desertification impact on SiwaOasis: present and future challenges. Res. J. Agric.Biol.Sci., 6(6):791-805.

Van Reeuwijk, L.P. (2002): Procedures for Soil Analysis, 6th ed.; International Soil Reference and Information Centre: Wageningen, Netherlands.

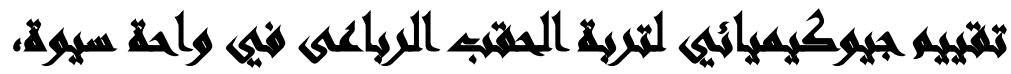 الصمراء الغريهة، همر}

[r]

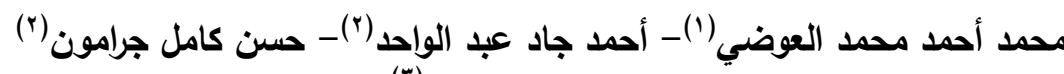

$$
\begin{aligned}
& \text { محمد غريب المالكى () }
\end{aligned}
$$

() إدارة المراقبة البيئية، قطاع الدراسات والتطوير ، هيئة المحطات النوية r ؟) قسم الجيولوجيا، كلية

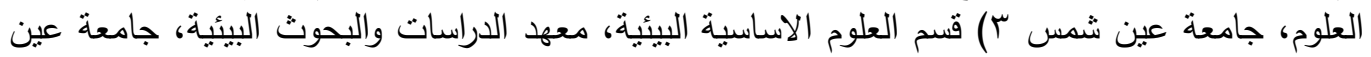

\section{المستخليف}

تم التحديد الكمي للمعاملات الفيزيقو - كيميائية والأيونات الرئيسية والعناصر الثقيلة لتربة الحقب الرباعى المزروعة وغير المزروعة في واحة سيوة. كما تم تطبيق التحليلات الأحصائية ثنائية المتغيرات

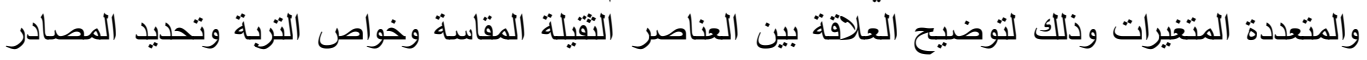

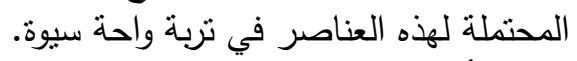

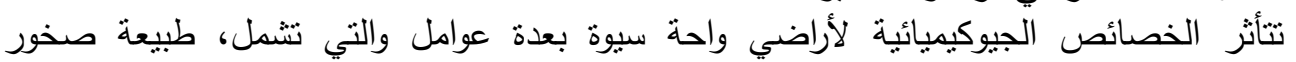
المصدر، الموقع الجغرافي، وعمليات تكوين التربة، ومدى التصريف والرشحة، تأنتير المياه الجوفية المالحة القربية من السطح والأنشطة الزئية واعراعية. الكلمات الدالة: مصر ، الصحراء الغربية، واحة سيوة، تربة الحقب الرباعي، التقييم الجيوكيميائي. 